\title{
the lakalakabulu area council of chiefs in vanuatu
}

\author{
Paul Vuhu \\ General Secretary of the \\ Lakalakabulu Area Council of Chiefs
}

AFTER MUCH PLANNING and research, the Lakalakabulu Area Council of Chiefs was established on 6th March 1996. This Area Council has authority over Nasalokoro, Lolovange, Saranavihi and Ambanga villages on North Ambae. The Council is well known throughout different communities on Ambae Island and Penama Province as a whole.

The Lakalakabulu Area Council of Chiefs has three main aims:

- $\quad$ to protect and safeguard the general welfare and rights of our indigenous people;

- $\quad$ to protect and promote our traditional values;

- $\quad$ to resolve disputes and disagreements in a customary way.

Since its inception, the Council has taken a leading role in resolving disputes based on local custom applicable within the Council's territorial jurisdiction. The Council has been involved in a range of disputes including land matters, family conflicts and minor criminal cases such as assault, theft, trespass and damage to property. In 1997 the Council made a special request to the government for the establishment of an Island Court and a resident magistrate at Penama Provincial Headquarters. While the government responded favourably to 
the Council's request nothing has yet been done to set up an Island Court on Ambae. The Council therefore remains the primary dispute resolution mechanism within its area of jurisdiction.

On 29 January 1997 the Lakalakabulu Area Council of Chiefs adopted a constitution and dispute resolution procedure. It made history in doing so as it was the first area council of chiefs to use the authority of the Constitution of the Republic of Vanuatu as a basis for establishing its own constitution. The Council's constitution states that:

the National Constitution recognises under Article 78(2) the need to set up customary institutions to resolve land disputes; and the National Constitution recognises under Article 52 the need for the establishment of village or island Courts with jurisdiction over customary and other matters ... therefore the Lakalakabulu Area Council of Chiefs ... do hereby adopt, enact and give themselves this Constitution.

The constitution provides solid foundations for the existence and work of the Council. Under the constitution, the composition of the Council was set at eight members. Two members are drawn from each of the areas that the Council has jurisdiction over. Of these eight members, there must be at least one representative from each of the church groups, youth groups, and women's groups in the area. The eight members of the Council are elected for a term of two years.

From 1998-1999 Lakalakabulu Area Council of Chiefs dealt with 74 minor criminal cases and 41 civil cases. Ninety per cent of these cases were dealt with satisfactorily. On occasion cases would be referred back to village councils or to families to resolve. The Council has its own concepts of how to punish and how to resolve problems. In the event of a dispute, the Secretary of the Council is responsible for notifying all parties of the relevant dispute resolution meeting. In disputes involving land the notice period must be at least two weeks. The Council can issue an official summons to attend that can be 
used to bring witnesses or alleged perpetrators of crime before the dispute resolution meeting. Four justices sitting together hear cases. If any of the parties thinks that a particular justice may be biased then that party can ask for the justice to be removed. Another justice, who all the parties agree to, will then be appointed. In this way any potential unfairness because of bias is removed. At any one time there are eight justices, with two being drawn from each area within the Council's jurisdiction. This procedure gives an adequate choice of adjudicators to the parties.

During a hearing all parties are given an opportunity to speak. Witnesses may also be asked to speak and may be questioned. If any party is unhappy with the decision arrived at by the justices they are entitled to complain. The matter will then be reconsidered. This reconsideration does not take the form of a separate appeal, but is a continuation of the same dispute resolution meeting. Only once all the parties are satisfied with the judgement is the matter considered to be resolved and the dispute resolution meeting over. This procedure is followed because the aim of dispute resolution meetings is to find a solution acceptable to all parties. If any party remained dissatisfied this could be the source of further disputes. To avoid this situation, dispute resolution meetings continue until all parties agree on an outcome. The Council has set maximum limits, in vatu (the local currency), for penalties that can be imposed at a dispute resolution meeting. All payments, whether fines or compensation, can be made in a customary way using our traditional materials such as pig tusks, mats and kava. These materials have significant value and meaning in our societies. People who wish to take a dispute to the Council must pay a set fee. This fee can also be paid for using traditional materials.

After five years as General Secretary of the Lakalakabulu Area Council, I have found that this system provides a very effective and respectful dispute resolution mechanism. It helps settle down the feelings of both the offender and the victim and is appropriate to our cultural heritage and living. Customary laws are still respected and form an important part of our 
cultural heritage. The Council's respectful approach can be contrasted with the introduced court system, which often leaves one or both parties of a dispute unsatisfied after a decision is made.

As well as providing mediation and dispute resolution mechanisms, the Council has initiated and conducted legal awareness and education programs in areas such as legal rights, intellectual property rights, freedoms and general information about the work of the police and of the courts. In doing this, the Lakalakabulu Council of Chiefs has been working very closely with other bodies of authority in the area such as the police, provincial government offices, churches, village councils of chiefs and other non-governmental organisations. The programs have contributed tremendously in advancing the work of the Council and the general level of the community legal education in the part of Ambae Island that the Council operates in.

To conclude, the Council has so far done a great deal in maintaining and restoring harmony and good order within its customary territorial jurisdiction. Access to courts is a major problem in rural communities, but the establishment of the Council has assisted in overcoming this problem. The work of the Lakalakabulu Area Council of Chiefs constitutes a model for the communities within the remote islands of the Republic of Vanuatu. Aware of the legal limitations on the powers of Vanuatu custom chiefs, it is the Council's wish to see legislative developments and reforms in that area so as to enhance the work of the Lakalakabulu Area Council of Chiefs. 